\title{
Higher Education Students' Challenges on Flexible Online Learning Implementation in the Rural Areas: A Philippine Case
}

\author{
Thessalou E. Gocotano, Mae Anthoneth L. Jerodiaz, Jenny Claire P. Banggay, \\ Harold B. Rey Nasibog and Marivel B. Go \\ College of Education, Cebu Technological University, Moalboal Campus \\ Poblacion West, Moalboal, Cebu, Philippines \\ https:/ / orcid.org/0000-0002-7958-1041 \\ https:// orcid.org/0000-0003-1889-1449 \\ https://orcid.org/0000-0001-7032-5052 \\ https://orcid.org/0000-0001-8307-0618 \\ https://orcid.org/0000-0001-9102-0805
}

\begin{abstract}
The COVID-19 Pandemic has led Higher Education Institutions (HEIs) in the Philippines to replace on-campus learning with flexible learning. This paper explores the students' challenges on flexible online learning implementation of the university in the rural area based on their background and experience. This employed quantitative and qualitative methods through a survey and an interview respectively sought to gather data from 639 university students. Data were analyzed with descriptive statistics and narrative analysis. Results revealed that most mothers are high school graduates, while fathers enjoy an elementary-level and belong to under low-income families. Most students possess just mobile phones and use mobile data as their primary internet access source, ranging from moderate to poor connection. Also, the majority are not fully equipped with enough skills in digital media. For challenges, students experienced the unavailability of a network, economic instability, digital divide, the shortage of digital devices, distractive learning environment, expensive internet data, health-related problems, lack of resources, lack of digital literacy skills, and loss of motivation .Hence, even if flexible online learning is the best solution for the university to replace face-to-face classes, it is not best applicable and suitable to all students living in rural areas or other places with an unstable network and students who belong to financially unstable families. Administrators and educators have to consider alternative learning modes that suit students' backgrounds during the pandemic, like using non-digital technologies.
\end{abstract}

Keywords: flexible online learning; rural university students; COVID-19 


\section{Introduction}

The outbreak of Coronavirus Disease (COVID-19) Pandemic significantly impacts daily life and caused massive disruptions worldwide (Chakraborty \& Maity, 2020). It emerged so suddenly that no one was prepared to accept its societal implications directly. The expenses associated with controlling and managing the pandemic are exorbitant, making even developing countries struggle to keep up (Haleem et al., 2020). The Philippines, in particular, was forced to adopt measures to counteract the spread of COVID-19, such as forbidding public gatherings and adopting social distancing. It also leads to closing schools, colleges, and universities resulting in nearly 28 million Filipino students in all academic levels remain at home and complying with the Philippine government's quarantine procedures (UNESCO, 2020).

All of which compelled Higher Education Institutions (HEIs) to switch to flexible teaching and learning. The Philippines' Commission on Higher Education (CHED) has issued recommendations for the adoption of flexible learning and teaching and provide definition anchored from Southeast Asian Ministers of Education Organization (SEAMEO) (2021) as a pedagogical approach that allows for time, location, and audience flexibility, including but not limited to, the use of technology. It also urged HEIs to deploy available versatile curriculum and other alternate forms of distribution in place of oncampus instruction (Commission on Higher Education [CHED], 2020). Such regulation also emphasized that HEIs and their instructors' exercise of discretion must be reasonable, transparent, and outcomes-based validated.

Certain HEIs have established proactive strategies to continue the learners' education, particularly the 3.5 million tertiary-level students enrolled in about 2,400 Higher Education Institutions (HEIs). The university in the rural area implemented Flexible Online Learning (FOL) that incorporates both synchronous and asynchronous learning modes and a mixture of methods. According to Singh and Thurman (2019), synchronous online learning entails real-time on-screen discussions, whereas asynchronous online learning happens offline where students can manage their own time. Such sudden implementation of FOL raised some challenges to students, parents, and educators, especially when Toquero (2020) revealed that numerous HEIs in the Philippines, both private and public, are unprepared to implement an online system. They still need to consider several aspects, including financial stability, network accessibility, technical equipment, and digital knowledge.

According to the literature, both students and teachers face several difficulties when engaged in online learning (Andersson \& Gronlund, 2017; Arinto, 2016; Baticulon et al., 2021; Dubey \& Piroska, 2019; Gilbert, 2015; Gillet-Swan, 2017; Islam et al., 2015). For instance, FOL removes the human connection, which reduces student participation, engagement, and the professors' ability to adjust instructional content and lectures (Shore, 2020).In addition, Friedman (2020) enumerated a number of challenges as technological difficulties, interruption, organizational skills, lack of motivation, understanding learning objectives, lack of peer review and direct interaction, adjusting to different technological 
advancements, and fear of the future. Hence, various sectors criticized the HEI's proactive measures in Flexible online learning. The petitioners contended that "ability to the internet connection and learning equipment has remained a luxury to this day, putting those with limited internet access at a disadvantage when it comes to online classes" (Joaquin et al., 2020, p.2). The 2019 nationwide survey confirmed such limited internet connection, which produced national and regional estimates of ICT indicators involving 43,838 sample households. According to the findings, specifically, in Cebu Province, where the university is located and where the participants reside, only 28.99 percent of the entire household have internet connection (National Statistics Office [NSO], 2010). As such, along with implementing flexible learning, the university has provided free modems to teachers and students to ensure internet access.

Though literature showed considerable research about flexible online learning even before the pandemic, it is not based on the Philippine context. Thus, this issue is yet to be studied more because of its relevance and minimal sources. Furthermore, there is a scarcity on the number of available literature on how COVID-19 influenced education (Bao, 2020; Sintema, 2020; Yan, 2020), particularly on the challenges faced by college learners in the rural areas of the Philippines. Hence, investigating this problem is worthwhile to consider. This study will provide the Commission on Higher Education, policymakers, other educational institutions, educators, and parents with such information and subsequently make the required modifications and steps to improve the implementation to create a more worthwhile teaching-learning experience.

\section{Review of Related Literature}

\subsection{Flexible Online Learning}

Distance education is a learning environment in which professors and learners are physically separated during classes, and various approaches using technological devices are utilized to enable student-teacher and student-student communication (Simonson et al., 2020; Tuckman, 2007). Remote education, elearning, online learning, and flexible online learning are all terms used to describe distance learning. FOL is interchanged with phrases like "open learning," "distance learning," "work-based learning," and "e-learning," which enable students to select their own time/pace, place, access, subject, and delivery method (George \& Luke, 1995). FOL has several descriptions, such as collecting concepts concerned with educational philosophies and structures, giving students more options, comfort, flexibility, and adaptation of the learner's needs (Shurville et al., 2008). It is learner-centered, promoting greater individuality and autonomy in students (Wanner \& Palmer, 2015), giving students options for where, where, and how they learn (Casey \& Wilson, 2005; Naidu et al., 2017). Llego (2020) described it as where the instructor serves as a facilitator, enlisting learners' active involvement via various technologies available over the internet when they are physically separated from one another during teaching. For Huang (2019) and Usher and Barak (2020), the internet and other technical equipment and tools and synchronous and asynchronous instructional delivery and academic materials are all used in a learning environment. Moreover, Markova et al. (2017), Muller et al. (2018), and Van 
Doorn and Van Doorn (2004) described it as a learning modality where students become more responsible for their learning since the learning mode requires them for greater participation and sometimes self-learning and discoveries.

Similarly, in the Philippines, FOL involves synchronous and asynchronous learning (CHE, 2020), where synchronous learning is a real-time online or distance education that follows a set class schedule and login times (Bonk \& Zhang, 2006; Means et al., 2010; Oztok et al., 2013). It ensures that at a specific moment, teachers and students communicate in a simulated virtual environment. Instructors also take attendance in these classes, much as they would in a lecture hall. Such synchronous mode includes video conference, teleconference, live chats, and live-streamed lectures that must be watched in real-time. Since it makes for a more interactive discussion of subjects, thoughts, and definitions, the synchronous online format is also an upgrade over classroom instruction. Furthermore, synchronous online learning provides a sense of pace and immediacy; videoconferencing allows students to ask classmates and teachers and get replies in the middle of a lecture (Means et al., 2010; Joan, 2013; Pappas, 2015). It also offers frequent opportunities for virtual conversation, individual support, and mentorship and requires a solid and steady internet connection (Llego, 2020).However, technical issues like slow internet, crashed hard drives, and dead batteries will turn into full-fledged GPAdraining disasters for synchronous learners (The Regents of the University of Colorado, 2017). Instead of signing in and taking the test, one can find himself cursing at the computer.

On the other hand, asynchronous learning occurs at one's favourable time (Finol, 2020; Joan, 2013; Oztok et al., 2013; Pappas, 2015). Although a tutor, a program, or course of study can include reading materials, lessons to see, assignments to complete, and exams to take, a student can access and complete these learning materials on his own time as long as the student adheres to the deadlines. Asynchronous learning resources include self-paced classes, modules, recorded and downloadable video lessons, lecture notes, and online discussions or social network websites (Villarin, 2020).

\subsection{Advantages and Disadvantages of Flexible Online Learning}

Such a new learning style entails some advantages and disadvantages. Its benefits include students working at their own pace, feeling more motivated and in control of their education (University of Perpetual Help [UPH], 2020), can participate in virtual classes, and access learning tools stored in the learning management system. Students are more responsible, attentive, and self-directed due to these online and offline learning interactions. Also, Joan (2013) pointed out that flexible learning aids in promoting quality education allow students to schedule their tasks around their passions and interests. It also holds their minds in an optimistic state and away from outside threats. Students should be aware of the importance of improving themselves through this learning to excel in their chosen field. They should arm themselves with a thorough understanding of technology to pique their interest and facilitate their learning efficiently and straightforwardly. 
Conversely, other studies noted disadvantages of flexible learning, such as concerns about social inclusion and peer culture, as well as the likelihood of values transmission in a "virtual" classroom (Edge \& Loegering, 2000; Gamage et al., 2020). It has been explained that students might learn less in such a setting than in a typical classroom because there is less human involvement in the learning process. There is also worry about the unnaturalness and consequences of online learning, which is the contradiction on how natural teaching and learning should take place (Adnan \& Anwar, 2020; Larreamendy-Joerns \& Leinhardt, 2006). In addition, there are tough questions about socioeconomic for online schooling in an underdeveloped world like the Philippines. Students in remote areas of the country lack access to roads or electricity, let alone digital devices and connectivity kits. Furthermore, even students in urban regions may have limited online access due to the current internet infrastructure. Consequently, there is an "internet gap" between those who have access and those who do not.

\subsection{Challenges Faced in Flexible Online Learning in the Rural Areas}

As a response to the COVID-19 pandemic, distant learning has taken the role of temporary remote instruction. Flexible online learning gives students a lot more choice in terms of how and when they engage; nonetheless, students' capacity to manage their learning becomes crucial (Sun \& Rueda, 2012). For other countries, the transition of the mode of learning was smooth, but for others, it was rough, those from underdeveloped nations with insufficient infrastructure, in particular (Pham \& Nguyen, 2020; Simbulan, 2020). Several main problems have been arisen throughout the transition to a new learning environment, including policy, pedagogy, logistics, socioeconomic considerations, availability of technological devices, and psychosocial aspects (Donitsa-Schmidt \& Ramot, 2020; Khalil et al., 2020; Gonzalez et al., 2020). Though flexible online learning is an excellent platform, some issues occur that affect both students and teachers. The pandemic harms students' behavioural and emotional functioning, notably focus and alleviating difficulties caused by seclusion, financial standing, health implications, and anxiety (Copeland et al., 2021). Also, concerns were expressed by students about learning and evaluation techniques and excessive task load, technical problems, and confinement (Fawaz et al., 2021).

Moreover, the students noted specific difficulties they had when taking online programs. Anxiety, sadness, inadequate internet access, and an unpleasant home learning environment are all factors that are exacerbated when students are disadvantaged or from distant locations (Kapasia et al., 2020). Additionally, other reported challenges include a lack of adequate equipment, limited studying space at home, student stress, and a lack of fieldwork and access to laboratories (Day et al., 2021, Tientcheu, 2021).Academically, while students may learn anything online, learning may be subpar, particularly in classes that need face-to-face interactions (Franchi, 2020). Learners in rural locations have significant hurdles in adjusting to modern lifestyles and learning, as seen by the extensive use of online learning management systems and low-technological applications (Dube, 2020). Because of a lack of infrastructure to connect to the internet, the learning management system, and low-technological applications, 
many rural learners in South Africa are excluded from teaching and learning. They need extra training, such as digital remediation programs, to use online collaborative tools (Welser et al., 2019), and are revealed to have lower selfassessment in online participatory skills.

A research discovered that students in flexible online learning might be lacking in opportunities to interact, receive feedback on their performance, and gain social support (Tuckman, 2007). In contrast, another study uncovered that internet-based settings could create a sense of isolation for students, making it more straightforward for them to attend or not to attend classes regularly (Cull, 2010; Rost, 2019). These ideas demonstrated that students in online learning have anxiety, which resulted in a lack of involvement. Due to the absence of interaction during online lessons, students are easily distracted by cell phones, dogs, deliveries, and other activities other than the ongoing online class (Amadora, 2020). She further stressed that in the absence of face-to-face interaction, it is assumed that pupils will be disinterested in the online course.

Internet connection is a common concern among instructors and students in rural areas. Since the Philippines remains one of Asia's slowest internet countries, Wi-Fi access is another problem. The country reported multiple students and instructors who need to climb mountains and trees to access the internet (Averia, 2020). The Philippines' sluggish internet connection provided a significant barrier to students, particularly those from rural areas or remote places (Adonis, 2020). Instructors in the Philippines suspected that the number of school dropout cases during the academic year 2020-2021 is due to poor network connection. Millions of learners battled to become acquainted with the new learning platforms triggered by the pandemic (Adonis, 2020). There are areas unreachable of the internet, and cell coverage is spotty and inconsistent; hence for students, the school has always served as a social network. As such, the internet connection and their isolation have grown due to the lack of both. However, some students have adapted well, solved problems, searched for opportunities, and applied their newly acquired skills to meet their new needs. Regardless of the causes that have distanced them from traditional educationclosure, technology advancements - they are most likely better prepared to deal with their new environment.

Furthermore, doing an online class in a rural setting has its own set of obstacles, and many students without smartphones or internet connectivity are left out (Hossain, 2020). To fill this need, some students have formed home study groups in which they share computers. Furthermore, instructors in the same village share phone numbers with the learners, and students visit their houses to seek help from their teachers (Hossain, 2020). Additionally, students in rural areas find it hard to access different online educational platforms (Macintyre \& Macdonald, 2011). However, the study noted that the focus on attainability and network does not dim the individual's willingness to learn in flexible learning. Students also experienced a geographical issue (Fleming et al., 2020). Suryaman et al. (2020) studied how individuals learn throughout the pandemic at home. Their findings revealed that students encountered several challenges in a home 
learning setting, including a lack of technological expertise, expensive Internet costs, and restricted interaction/socialization amongst and among students.

\section{Objectives}

This paper aims to explore the students' challenges on flexible online learning implementation of the university in the rural area based on their background in terms of their family income, parents' educational qualification, availability of technology, accessibility of internet connection, type of internet connection, and level of digital literacy and their experience.

\section{Methodology}

\subsection{Research Design}

This study utilized descriptive quantitative and qualitative design. Survey and interview questionnaires were utilized to discuss the measured variables. The quantitative approach focuses on accumulating numerical data and generalizing it to describe a particular event (Babbie, 2010; Muijs, 2010). Whereas, qualitative research is a type of investigation that examines information provided via language and behaviour in real situations (Lincoln et al., 1985). It emphasizes the necessity of reviewing variables in their natural environment (Astalin, 2013; Richards, 2006).

\subsection{Research Participants and Context}

The study was conducted in a university, a satellite campus situated in the Southwest of Cebu Province, Philippines, with program offerings accredited from the Accrediting Agency of Chartered Colleges and Universities in the Philippines, Inc. (AACUP). The environment was selected based on the ability of the university to provide the necessary information for the study.

The participants in this study were the 639 (511 females and 128 males) first to third-year college students of the said university randomly selected in the first semester in the academic year 2020-2021, during the COVID-19 lockdown from the different programs: Education, Hospitality Management, Fisheries, and Industrial Technology. Further, the participants are residing in various towns of Southern Cebu Province. The population density in these areas is lower, and only a few structures have been constructed. Great distances separate the people who live in these areas, and their primary means of subsistence are farming, forestry, and fishing. Likewise, it should be emphasized that the complete sample does not reflect the entire population, but it is deemed adequate for demonstrating the objective of this study.

\subsection{Methods of Data Collection and Instrument}

The quantitative data were collected using an electronic survey method through Google Form with respondents' consent. The survey questionnaire is a researcher made containing the college students' background that focused on the personal profile of the respondents guided from the related literature that includes parents' educational background and socioeconomic status. It also includes learner's online learning profile anchored on CHED Memo No. 04 series of 2020, guidelines on the implementation of flexible learning 2020, as follows: 
availability of technology, level of digital literacy, type of internet connection, and accessibility of internet connection. The instrument was reviewed by two expert educators to ensure whether or not it measured the variable of interest. Qualitative data were gathered through in-depth virtual interviews via messenger chats and calls. The interview questionnaire contained an openended question intended to collect data on the experiences of students concerning their challenges encountered in the use of flexible online learning modality. The researchers did not set a time restriction for the interviews, simply relying on the students' availability. All interviews were conducted by combining formal and informal discussions.

In line with the Data Privacy Act of 2012 (RA 10173), the researchers of this study were committed to protect and secure personal information obtained in the process of data gathering. The respondents' participation is voluntary both for survey and interview designs. If they feel uncomfortable, they are free to discontinue their involvement in the research at any stage. The data gathered were solely used to serve as a reference to measure the parameters of this research study and nothing more. Researchers stored the information for one semester, after which the physical records were disposed of or destroyed following the disposition process provided by the National Archives of the Philippines. An electronic invitation letter that contained the Google Form link and informed consent was sent to the respondents via e-mail and messenger chats.

\subsection{Data Analysis}

The quantitative data from the survey questionnaire reflecting the respondents' background was investigated using descriptive statistics. Conversely, the indepth interviews were analyzed using narrative qualitative analysis. Narrative analysis, also known as narrative inquiry, is a qualitative research technique in which the researcher explores the narratives individuals tell by asking specific questions for a particular reason. According to Polkinghorne (1995), the report is the basic scheme for connecting individual human acts and events into interconnected elements of a comprehensible composite. According to a traditional narrative approach assumption, people share stories to help structure and make sense of their lives, and their stories accounts are realistic and purposeful. A narrative review allows the researcher to see how respondents impose their order on reality and the environment by drawing on their interactions between events and actions through stories. This study utilized narrative analysis because the researchers wanted to get a broad, holistic, and dynamic view of their topic. Also, the researchers clustered the responses into themes and verified them to ensure accurate interpretation. 


\section{Results and Discussions}

Table 1: Respondents' Background

\begin{tabular}{|c|c|c|c|}
\hline \multicolumn{2}{|r|}{ Variable } & Frequency & Percentage \\
\hline \multirow{7}{*}{$\begin{array}{l}\text { Mother's Educational } \\
\text { Background }\end{array}$} & Elementary Level & 122 & 19.09 \\
\hline & Elementary Graduate & 91 & 14.24 \\
\hline & Secondary Level & 115 & 17.99 \\
\hline & High School Graduate & 158 & 24.73 \\
\hline & College Level & 86 & 13.46 \\
\hline & College Graduate & 67 & 10.49 \\
\hline & Total & 639 & $100 \%$ \\
\hline \multirow{7}{*}{$\begin{array}{l}\text { Father's Educational } \\
\text { Background }\end{array}$} & Elementary Level & 177 & 27.70 \\
\hline & Elementary Graduate & 72 & 11.27 \\
\hline & Secondary Level & 122 & 19.09 \\
\hline & High School Graduate & 121 & 18.94 \\
\hline & College Level & 61 & 9.55 \\
\hline & College Graduate & 86 & 13.45 \\
\hline & Total & 639 & $100 \%$ \\
\hline \multirow{8}{*}{$\begin{array}{l}\text { Family Monthly } \\
\text { Income }\end{array}$} & Less than $11,690.00$ & 576 & 90.14 \\
\hline & Between 11,690.00 - 23, 381.00 & 41 & 6.42 \\
\hline & Between 23, $381.00-46,761.00$ & 10 & 1.56 \\
\hline & Between 46, $761.00-81,832.00$ & 1 & 0.16 \\
\hline & Between 81, $832.00-140,284.00$ & 2 & 0.31 \\
\hline & Between 140, $284.00-233,806.00$ & 4 & 0.63 \\
\hline & At least $233,807.00$ & 5 & 0.78 \\
\hline & Total & 639 & $100 \%$ \\
\hline \multirow{6}{*}{$\begin{array}{l}\text { Availability of } \\
\text { Technology }\end{array}$} & Laptop & 103 & 13.00 \\
\hline & iPad & 7 & 0.88 \\
\hline & Android Phone & 619 & 78.16 \\
\hline & Tablet & 27 & 3.41 \\
\hline & Computer & 36 & 4.55 \\
\hline & * Multiple Answers & 792 & $100 \%$ \\
\hline \multirow{5}{*}{$\begin{array}{l}\text { Type of Internet } \\
\text { Connection }\end{array}$} & Mobile Data & 564 & 69.12 \\
\hline & Wireless Fidelity & 234 & 28.68 \\
\hline & Broadband & 10 & 1.23 \\
\hline & Cable & 7 & 0.85 \\
\hline & * Multiple Answers & 816 & $100 \%$ \\
\hline \multirow[t]{4}{*}{$\begin{array}{l}\text { Accessibility of } \\
\text { Internet Connection }\end{array}$} & Strong & 6 & 0.94 \\
\hline & Average & 351 & 54.93 \\
\hline & Poor & 282 & 44.13 \\
\hline & Total & 639 & $100 \%$ \\
\hline \multirow{4}{*}{$\begin{array}{l}\text { Level of Digital } \\
\text { Literacy }\end{array}$} & Advanced & 206 & 32.23 \\
\hline & Proficient & 178 & 27.86 \\
\hline & Beginner & 255 & 39.91 \\
\hline & Total & 639 & $100 \%$ \\
\hline
\end{tabular}




\subsection{Respondents' Backgrounds}

\subsubsection{Parents' Educational Background}

Data on parents' educational background is presented in Table 1. The majority of the mothers $(24.73 \%)$ are high school graduates, $(19.09 \%)$ enjoy an elementary level, (17.99\%) have secondary level, (14.24\%) are elementary graduates, $(13.46 \%)$ possess college level, and $(10.49 \%)$ are college graduates. Regarding the fathers' highest educational attainment, the majority of the fathers177 $(27.70 \%)$ have an elementary level, (19.0\%) possess secondary level, and (18.94\%), $(13.45 \%),(11.27 \%)$,are high school graduates, college graduates, and elementary graduates respectively, while $(9.55 \%)$ have college level. Such results reflect the parents' poor capability to satisfy the needs of their children and their ability to help and support them in their academic pursuits in flexible online learning.

As established by several studies, parents' educational level has a positive influence on the students' academic achievement (Gooding, 2001; Idris et al., 2020; Khan et al., 2015; Schwanz et al., 2014). Hence, parents who are welleducated or went through it all from high school to college would know and understand their children's needs and necessities, primarily when classes are held online, and it needs some stack of money to keep up. Moreover, parents who receive a good education could help their children with their assignments, activities, and even projects because they have something to share and improve students' performance. It implies that most parents cannot fully assist their students' educational needs based on the present results, especially during this online learning delivery due to the low educational level, and subsequently may affect their students' achievement. Okafor et al. (2018) pointed out that such parents with low education levels would likely depend on the teachers and instructors to make their children smarter instantly. However, it is not possible at this time of the pandemic resulting in additional challenges to students learning online.

\subsubsection{Family Income}

Family income may be an essential variable in the study since this parameter has been concluded to affect learners' ability to learn and access online classes ( $\mathrm{Lv}$, 2017). As displayed in table 1 , most of the respondents $(90.14 \%)$ belonged to a low-income family with a monthly income of less than 11,690.00, $(6.42 \%)$ between 11,690.00 - 23, 381.00, (1.56\%) between 23, $381.00-46,761.00,(0.78 \%)$ at least $233,807.00,(0.63 \%)$ between $140,284.00-233,806.00,(0.31 \%)$ between 81 , 832.00 - 140,284.00, and (0.16\%) between 46, 761.00 - 81,832.00.

According to a Philippine Statistics Authority survey (PSA) (2020), Filipinos living and working in the countryside continue to be poorer than those in metropolitan areas. Preliminary estimates of poverty incidence, or the proportion of poor Filipinos whose incomes are insufficient to meet their basic needs, it has been revealed that farmers (31.6 percent in 2018, down from 40.8 percent in 2015), fisherfolk (26.2 percent, down from 36.9 percent), and people living in rural areas (24.5 percent, down from 34 percent) had the highest rates in 2018 (Philippine Statistics Authority [PSA], 2020). 
In addition, the Philippine Statistics Authority (2018) reported on a food threshold of PHP 7,337 as the primary wage required to satisfy basic food needs while meeting the dietary requirements established by the Food and Nutrition Research Institute (FNRI) to ensure economic and social productivity. In opposition, the poverty threshold $(10,481)$ is the minimum income required to meet basic food and non-food needs such as clothing, fuel, and lighting. Such a report serves as a foundation for imagining the participants' economic situation. According to the present findings, most participants came from low-income families earning less than the poverty line. Their earnings are insufficient to cover their basic needs, and they occasionally struggle to pay their bills, even more, acquiring learning resources for online learning.

Since family income influences college students' experiences and academic performance (Lin \& Lv, 2017), it provides comfort, a positive attitude, and a healthy environment, which result in increasing their academic performance (Saifi \& Mehmood, 2011). The respondents may encounter significant difficulties in their performance while learning through online classes. As emphasized by Morgan et al. (2009), low-income students develop academic skills slower than those students from higher-income groups. In addition, low-income students have a substantially lower success rate in science, technology, engineering, and mathematical fields than students who do not come from disadvantaged families (Doerschuk et al., 2016). Nevertheless, students from low-income families are also responsible enough to find a strategy to cope with their situation. For example, they force themselves to find their income to sustain their needs while learning online education, yet sometimes they would miss attending their online class.

\subsubsection{Availability of Technology}

The availability of technology is an essential variable in the study, for it may affect learner's capacity to learn and complete academic tasks in online instruction. The study results showed that students' most available device is a mobile phone $(78.18 \%)$ for attending online classes and completing academic activities (e.g., making word documents, video presentations, PowerPoint presentations, etc.). Further, the result reflected that only a few respondents, about $(20 \%)$, own other gadgets, either laptop $(13 \%)$, tablets $(3.41 \%)$, computers $(4.55 \%)$, and iPads $(0.88 \%)$.

Mobile phones are portable devices that offer technological tools. Most students own at least one device, and most of that is a cellular phone. In the Philippines, $79.05 \%$ of the population have mobile phones like android and smartphones to access the World Wide Web and do online activities (Sanchez, 2020). In addition, the majority $(93 \%)$ owned a smartphone for the medical students, and many (83\%) also had laptops or desktop computers. It can contain downloadable educational applications such as WPS, Google Classroom, Google Meet, Gmail, and Zoom. Utilizing mobile phones for class video conferences is less costly since it consumes lesser data than laptops and computers. However, mobile phones cannot install software such as SPSS. Thus, other devices (i.e., laptop, desktop, and others) are essential. 
Laptops, on the other hand, are also portable devices but less portable than mobile phones. In addition, it offers different advantages. Laptops are convenient for students because they enable them to have efficient note-taking and document-making. It also allows students to create reports, class presentations, and videos faster using different presentation platforms such as PowerPoint, Slide Share, Google Slides, and others.

The present results are similar to the outcomes of Cheung (2012) that in distance learning, mobile devices are commonly used by students for education, and other gadgets, tablets, and computers are not yet widely used. He further enumerated their primary usage, such as doing the assignment, reading ebooks, browsing the internet, checking e-mails, chatting, and social networking. However, there is a limitation in mobile usage. Put differently, it is determined not only by the technological characteristics and limits of mobile devices, but also by the nature of the learning activities (Cheung, 2018). Further, a study that was conducted by Hampton et al. (2020) revealed that those students who rely only on a cell phone for Internet access have more significant performance gaps than those who do not have access to the internet at home. Because students are deficient with online learning devices, Chua et al. (2020) suggested that for the e-learning assessment in the Philippine setting, teachers should consider the device, among others.

\subsubsection{Type of Internet Connection}

Among the internet sources used by the students in online classes, the majority $564(69.12 \%)$ are mobile data, $234(28.86 \%)$ followed by Wireless Fidelity (Wi-Fi), $10(1.23)$ are broadband, 7 or $(0.85 \%)$ are cables, and only $1(0.12 \%)$ is a hotspot.

Nowadays, different types of internet connections had risen to cater to the needs of internet users, either for them to get a better connection or to choose which is more affordable. As a result, there are many internet connection types: wireless fidelity, broadband, cable, hotspot, etc.

It was revealed above that most of the students use mobile as their online learning device because data was widely used as their source of the internet. The use of mobile data is not harmful at all, as it is known as a convenient type of internet connection. Moreover, it is no hassle because it does not need to be connected to an outlet other than wired internet sources such as modems and others. However, mobile data has its limitations; the internet connection in mobile data is not too fast. The obtained result is in contrast to the findings of Baticulon et al. (2021) in which the majority of the students in the Philippines $(79 \%)$ used post-paid internet subscriptions, while only a few $(19 \%)$ used prepaid mobile data to access online resources.

\subsubsection{Accessibility of Internet Connection}

As displayed in Table1, most of the respondents (54.93\%) have an average internet connection, while $(44.23 \%)$ have a poor internet connection, and very few $(0.94 \%)$ experienced a strong internet connection. These findings imply that students are at a disadvantage zone in accessing different search engines to aid their learning in online instruction. 
The role of the internet connection is one of the significant parts of an online class. In the Philippines, people are dealing with poor internet connections. Some places in the country had no access to a strong network. Senthil (2018) pointed out that internet connection is a resource that helps students search and find relevant information that would help them complete their academic tasks and performances. However, such poor connection leads to misalignment of instruction from the instructors due to unclear voices and late joining the class. With this, students may not be motivated to learn instead to comply with the requirements.

Despite the effort of the university to provide technological devices to all the students to ensure their access to online learning, many have not used them, as there is no signal in their areas. The struggle to access an internet connection can put a student in a disadvantageous situation. Dhawan (2020) specified that the lack of appropriate digital tools, no internet connections, or shaky Wi-Fi connections might pose a lot of problems, causing many students to miss out on learning possibilities.

Rural regions in the Philippines are less likely to have the infrastructure to enable the broadband internet connection, and high-speed home internet access is less widespread (Hampton et al., 2020). Students with slower Internet connections struggle to engage in online activities that demand more bandwidth, such as video chatting with classmates, discussing academics, conducting research, and seeking course content (Hampton et al., 2020; Asio et al., 2021). The same findings from Wickramanayake and Muhammad Jika's (2018) study showed that inconsistent internet connections is one of the hurdles for students, suggesting that internet connectivity will be a major problem for students' online learning.

\subsubsection{Level of Digital Literacy}

The level of digital literacy variable has been seen as an essential factor in students' academic performance online (Abbas et al., 2019). The result showed that the majority of the respondents are beginners $(39.91 \%), 206$ or $(32.23 \%)$ are digitally advanced, and $178(27.86 \%)$ are digitally proficient. This suggests that most of the respondents are not fully equipped with enough skills in digital media. However, the result also revealed that some of the respondents are possessed with digital skills and are digitally literate.

Digital skills include understanding hardware and software applications, managing privacy, basic online operations, and creating content. Digital literacy matters the most among learners, especially during a pandemic since classes are held online. The result noted that since most of the students are only beginners, this may affect their ability to comply with different academic tasks such as video and presentation making by using different platforms. On the other hand, students with advanced and proficient digital skills are at an advantage situation in learning online. Abbas et al. (2019) explained that basic digital literacy skills empower students to perform better in online classes. Students can achieve impressive and excellent outputs, such as integrating different effects and shots 
in their video presentation and utilizing other platforms during class reporting or discussions.

Bergdahl et al. (2020) cited the work of Nouri (2018) that college students learn in a mobile, flexible, and multimodal manner by leveraging the capabilities of various technologies and utilizing digital skills about multimodal literacy. Hence, having specific digital skills creates favourable conditions for engaging in productive learning technologies.

\subsection{Experiences by the Higher Education Students in Flexible Online Learning}

\subsubsection{Unavailability of Network}

The research found out that despite that the university has provided Wi-Fi modems to all the university students, the innovation of online classes is still hampered by the unavailability of the network, especially in the mountainous areas. In an interview, students said that they are not able to use the Wi-Fi modem because the location of their house does not have enough network signal. In the interview, a student claimed that she needs to go to other places to connect to the internet. On the one hand, another respondent said:

"Access to the network is making studies harder, especially during quizzes and examinations. I go to areas near the national highway for me to attend virtual classes submit activities. Also, access to a network is becoming more difficult during the rainy season."

Another student highlighted that:

"Some of the professors will mark us, the students absent whenever we are not able to attend an online discussion on time due to poor and unstable internet connection."

These claims supported the result above that only $(0.94 \%)$ of the respondents experienced a strong internet connection while a considerable number $(44.3 \%)$ of respondents revealed poor network access.

According to survey data issued by the Social Weather Stations (SWS) (2021) (The Manila Times, 2021) only 39\% of Filipino households with members enrolled in online distance learning have strong internet connection. The students' experiences on the unavailability of a network in their areas is an issue that the teachers and administration should consider. This result implied that even if online learning is the best solution to the loss of face-to-face classes, it is only applicable and suitable to students living in urban areas or other places with stable networks. To this end, students who can make the best use of online classes are already digitally literate and have sufficient access to a stable internet connection (World Bank, 2020).

Marasigan (2020), the International Telecommunications Union (ITU), has identified what it deems "worrying gaps" in connectivity and Internet access among least developing countries. According to the ITU, roughly $17 \%$ of the rural population in the least developed nation's lives in areas with no mobile service, while a $2 \mathrm{G}$ network only covers $19 \%$ of the rural population. According 
to the Philippine Statistical Authority's National ICT Household Survey (2019), $17.7 \%$ of all households in the Philippines have access to the internet. In addition, seven out of ten barangays lack access to fiber-optic connections, and $64 \%$ lack a cellular tower. According to the National Telecommunications Commission (NTC, 2015), the situation is significantly worse in some areas, which are all not served or underserved. According to the most recent International Telecommunications Union (ITU) data (Marasigan, 2020), the installation of mobile-broadband networks is expected to decelerate in 2020.

According to Araneta et al. (2021), in the Philippines, urban areas have better connectivity, whereas rural areas have a less digital infrastructure. According to the data of the Department of Information and Communications Technology (DICT) (2017), urban families have a more effective internet connection rate than rural households. Metro Manila households have the highest rate of access at $32.3 \%$. The virtual world has made productivity a privilege. People without it are left behind, missing out on everything from necessities and outstanding education to good work and reskilling chances. The challenges facing the Philippines and other countries in offering consistent internet availability, accessibility, and affordability in a post-COVID world have never been higher.

\subsubsection{Shortage of Devices for Online Learning}

Another challenge that the students experience in online learning is the lack of technological devices to be utilized. Learning through online classes requires a good gadget. It requires good quality smartphones, laptops, and computers that students can use to keep up with the activities. From the data gathered on the profile in online learning, the most available device is Android Phones which comprises $(78.16 \%)$ of the total sample. In an interview, a respondent uttered that:

"Mobile phone is only compatible with low-tech teaching applications such as Google Classroom, Google Meet, and Zoom. It cannot install math software. Also, creating documents, video, and report presentations are somehow difficult when using mobile phones."

Another participant testified that:

"It is hard for me to cope with my study because I don't own a good quality smartphone. Every time our teacher sends assignments or activities online, I cannot easily view it, and I still need to borrow a phone from my friends".

It has already been noted from the result of the survey that $(78.18 \%)$ of the respondents have utilized mobile phones alone while attending classes in flexible learning. Hereof, the need for digital devices is necessary for students while learning online, and the lack of these devices can affect their performance and may hinder their chances of learning. Typically, this problem usually occurs to those students who belong to low-income families. Therefore, they will be left out in this remote learning (Salman, 2020). The National Council of Educational Research and Training [NCERT], 2020) noted that in conducting online classes, 
the school should address the following problems: unavailability of digital resources and inaccessibility to the network.

\subsubsection{Distractive Learning Environment}

The data gathered from the interview revealed that the students find their home as a distractive learning environment. There are numerous interruptions such as noise from transportation machines, talkative neighbours, and noise from animals. One of the respondents asserted that:

"During synchronous class, I cannot turn on my device's microphone all the time since there is background noise. If I have a report, I look for a quiet place, but still, there is noise coming from animals."

Also, most of the students do not have their rooms, personal space, place, and own table for an online class. A respondent shared that:

"Online learning is difficult for me. I don't have a room where I can attend classes comfortably and with less distraction. So I have to go outside to find a place that is at least quiet and with a good network."

Some respondents said that other mobile applications such as Facebook and Instagram kept them from not doing academic tasks, for it became their stress reliever from the heavy workloads. These applications made them distracted big time from making their projects and worksheets because, as they have said, scrolling through their feeds is much easier and less stressful than doing their actual tasks. The reports implied that the student's learning environment is a factor that can affect their performance and behaviour in attending classes. Implementing flexible learning leaves no choice for the students to take their lessons in their respective homes. The research also revealed that only a few learners in rural areas in the Philippines have a convenient learning environment at home.

According to research, students who take online courses are subject to more distractions than those who take face-to-face sessions, which impact their academic performance (Turner, 2020). The unexpected appearance or interruption of family members, friends, or pets during the online teaching and learning process may cause disruption or diversion of online learning participants' attention (Adedoyin \& Soykan, 2020). Researchers also noted that students' homes are not always conducive for academic work and concentration; residences may be noisy and distracting environments (The Irish Times, 2020). As a result, academic performance suffers (Lepp, 2019).

\subsubsection{Expensive Internet Data}

Students also reported that Cebu Technological University had provided them with free Wi-Fi modems with a special price for loads lower than the regular during the interview. Internet data is still expensive to have effective online learning. Moreover and as mentioned above, most of the students belong to a family with low incomes. This situation is worsened during the pandemic because most of their parents lose their jobs. In an interview, a student-leader said: 
"I don't have load allowance given that the price of basic needs increases. So I go to school every day to connect the university's free WiFi access and do my duty as a student leader and as a student as well."

In this regard, the study found that costly data stymies online learning, putting students and teachers at a disadvantage zone. The students find flexible online classes as an expensive learning modality, especially during this pandemic. Most of their parents lost their jobs or with just temporary employment. Adedoyin and Soykan (2020) described that students with a low socioeconomic status who cannot afford a broadband connection are the most likely to fall behind or face additional difficulties in interacting with others in online learning.

In terms of cost, the Philippines is seen as one of the countries that has an expensive internet connection, in which Salac and Kim (2016) revealed that Philippine Internet users pay $\$ 20.35$ per megabit per second, compared to the global average of $\$ 5.21$ per megabit per second. In terms of the cost of Internet connection per Mbps, the Philippines ranked 161st out of 202 nations. The fact that there are only two major Internet service providers in the country, it is therefore one of the leading causes of the country's high internet costs. Prices have remained high due to a lack of competition in the market.

Moreover, the fact that the internet connection in the Philippines is very pricey, the Philippines ranks 82nd on the Internet Affordability Index, which assesses how long it takes to get the cheapest mobile and broadband internet in the country. Only Guatemala, Costa Rica, and Albania rank higher. According to the data, it takes 1,994 seconds of effort to afford the cheapest mobile internet in the country and 75 minutes to afford the most affordable broadband Internet (Esquire Philippines, 2020).

\subsubsection{Health-Related Problems}

The researchers also found out that students have experienced health-related problems while attending online classes. The participants said that they are given overloaded with academic activities. They are not able to manage their time anymore. Some of them got health problems such as headaches, eyestrain, and back pain due to a longer time spent on technology devices. In an interview, it has been reported that:

"We are given many activities, reports, exams, modules, and video presentations to the point that I cannot balance my time anymore. Sometimes, I sacrificed my good sleep and mealtime to submit the activities on time."

Additionally, the respondents reported that they usually sit during their classes from early in the morning and sometimes until in the evening and that caused back pain. Also, they experienced having eyestrain since online courses require technological devices, and the respondents are always on their phones and laptops. In this regard, flexible online learning causes health problems, specifically when students are tasked to do many digital works and activities. This problem can affect learners' willingness to perform well in the class. 
One of the most significant implications of the shift to online learning is student health, particularly sleep patterns. Students are concerned about poor physical conditions. In other terms, they spend most of their time attending online classes and completing the activities, leaving them with little or no opportunities to engage in physical activity (Rotas \& Cahapay, 2020). They get eyestrain and headache as a result of too much exposure to gadgets. Students also revealed the issue of mental health struggles. They feel sick whenever they had many activities to do, have slow internet, and are without someone to ask (Rotas \& Cahapay, 2020). Cueto and Agaton (2021) noted that stress and anxiety are the expected health effects whenever students suffer difficulties. In addition to the adverse health effects of disrupted sleep cycles, increasing internet use can influence students' physical and mental health. Jennifer Katzenstein, head of psychology and neuropsychology at Johns Hopkins All Children's Hospital, has seen the effects of distant learning on children of all ages. For college students, Katzenstein stated that they struggle to create a distraction-free atmosphere and develop the required organizational skills to remain on top of their tasks (Balram, 2020). These challenges might impact students' mental health; screen time consumption, particularly for non-academic pursuits, has increased sadness, anxiety, and reported concentration difficulties.

\subsubsection{Lack of Resources}

During the interview, students also referred that they find online education hard. They have fewer chances to discuss hard lessons with their classmates, teachers, and even parents. A respondent said that:

"Regarding the course subjects that I find difficult to understand, I cannot ask help from my parents. Both of my parents are only elementary graduates, and they cannot relate to the lessons I have during college."

This scenario portrayed that flexible learning puts students with parents who have low educational attainment at a critical situation. In some cases wherein the parents are not well-educated and lack knowledge and understanding in the education field, they would most likely depend on the teachers and instructors to make their children smarter instantly (Okafor, Owede, Uyanne, \& Chibundum, 2018). Furthermore, educated parents will most likely have a better job and provide the necessary devices for their children to attend online classes comfortably.

\subsubsection{Lack of Digital Literacy Skills}

The world has become digital; however, during the interview, many respondents uncovered that they are only equipped with the basic skills in utilizing their mobile phones and laptops. In attending classes online, students revealed that they find it challenging to manoeuvre their digital tools, such as editing videos and making report presentations. A respondent highlighted that:

"Editing videos and report presentation is time-consuming in my case since I have first to explore how to do such. My lack of digital skills is dragging me down in this online mode of learning." 
Adedoyin and Soykan (2020) further explained that as educational activities in this pandemic are transformed digitally, libraries must pursue this trend to supply adequate service to faculty, students, and other stakeholders through digital libraries. As such, students and teaching staff with low digital skills will experience difficulty in utilizing the digital libraries since Omotayo and Haliru (2020) identified digital competence as a variable with a positive correlation and significant effects on the use of digital libraries by higher education students.

\subsubsection{Losing Motivation}

The challenges mentioned above lead students to slowly lose motivation to continue the formal study in the university amidst the COVID 19 pandemic. During the interview, a student said that:

"I feel exhausted in this online learning. I don't have gadgets and other devices to be utilized. Also, the network in our place is unstable. I am almost always absent or late during synchronous class."

From the discussion above, it is clear that students find an online class a big challenge in pursuing their dreams. Students lack motivation due to constraints in learning online. Not all students are lucky enough to have good resources and belong to a well-off family. It also showed that students' profile in an online class is a factor that can affect their behaviour and performance in the class.

Although motivation is a multifaceted construct that is regularly linked to academic accomplishment, few theories consider students' lack of motivation as an explicit motivation factor. In the Philippines, various groups encourage the government to begin working on the safe and progressive implementation of face-to-face sessions in schools, claiming that distant learning is causing students to lose interest in their studies. Franz Beltran, president of the De La Salle University Senior High School Student Council, said that after discovering that their "learning environment" was "not conducive," several students have dropped out of online classes (Perez, 2021). Because of some reasons, many students continue to lose their motivation and morale every day while studying through this online mode (Perez, 2021). On the other hand, from the study of Avila et al. (2020), their research findings imply that through sufficient support, help, and encouragement, students can be motivated to learn online despite the obstacles.

The unpredictability of timetables from instructor to teacher and the various techniques that each teacher takes with his/her online classroom can keep track of what is assigned challenging (Turner, 2020). While a lack of desire has previously made keeping up with academic work more challenging, students have frequently reported that their workload has increased after switching to online study. The need for all teachers to provide enough activities to their pupils to comprehend a topic has resulted in a barrage of time-consuming chores that some have deemed superfluous busy work (Turner, 2020). Research conducted from 405 high school students and 305 college/university students in the Philippines revealed the following core themes of reasons for low motivation: beliefs and attitudes about the self and the subject, perceptions of 
the teacher's competencies, and distractions provided by social support systems (Salanga \& Bernardo, 2016).

\section{Conclusion}

It was concluded that implementing flexible online learning of the university as a replacement to on-campus learning created some challenges for students in rural areas, as revealed by their background and experiences. Although it was thought such implementation is the best solution to replace face-to-face classes during this pandemic by the university, it is not best applicable and suitable to all students living in rural areas. The difficulty in internet access, which is the root cause of the struggles experienced by said students during the implementation of flexible learning, and other factors such as lack of gadgets, load, etc., may also significantly affect their learning experiences. With the lack of proper monetary allocation for the students' online classes, they could only rely on their mobile data connection to access the internet. Indeed, this can't guarantee a good learning impact and outcome, since mobile data is slower than other internet connection types like Wi-Fi. With the lack of proper technological devices, students cannot be very familiar with how these educational applications work. The presence of health problems experienced by the students during the online classes was another negative consequence of implementing flexible online learning. Therefore, the HEI's administrators and educators must consider such information in deciding implementation of alternative mode of learning. This paper highlighted the need to consider students' backgrounds and experiences in implementing online learning-related modalities. Such information is essential, as it would guide educators and policymakers to come up with best academic plans suitable to students' status, particularly on the provision of educational support to address the students' needs in flexible online learning.

\section{Recommendations}

Concerning the context of this research, we have these recommendations for good practice in supporting online classes of students living in rural areas. First, the school should provide training on technological proficiency and expertise for both teachers and students. Second, the school administrations must have adequate infrastructure and primarily internet facilities to establish flexible learning. Third, besides conducting classes online, the students should also be given study materials and class activities that they can freely do at home to address the gap of internet connection for students living in rural areas. Fourth, the school administration should consider those students who belong to lowincome families in affording them free online tools that they can use to attend online classes. Lastly, HEI's administrators should also recognize non-digital learning modes or other appropriate alternatives convenient to students to ensure productive learning.

\section{Limitations}

Since this study involves one public university and province only, thus the results may not reflect students' fundamental and complete challenges on flexible online learning in the rural areas. Hence, future research has to consider 
other rural areas and private institutions to have comprehensive data. Also, the scope of challenges tackled in this study may be minimal as it only focuses on the aspect of students. Future studies may consider other areas to have a holistic view of the challenges brought by the pandemic on the sudden implementation of online learning.

\section{References}

Abbas, Q., Hussain, S., \& Rasool, S. (2019). Digital literacy effect on the academic performance of students at higher education level in Pakistan. Global Social Sciences Review, 4(1), 154-165. https://doi.org/10.31703/gssr.2019(IV-I).14

Adedoyin, O. B., \& Soykan, E. (2020). Covid-19 pandemic and online learning: The challenges and opportunities. Interactive Learning Environments, 1-13. https://doi.org/10.1080/10494820.2020.1813180

Adonis, M. (2020). Challenges hound online opening classes. https:// newsinfo.inquirer.net/1344074/challenges-hound-online-opening-ofclasses

Amadora, M. (2020). Common problems that occur during online classes. https://mb.com.ph/2020/09/18/common-problems-that-occur-during-onlineclasses/

Adnan, M., \& Anwar, K. (2020). Online learning the COVID-19 pandemic: Students' perspectives. Journal of Pedagogical Research, 1(2), 45-51. https:// doi.org/10.33902/JPSP.2020261309

Andersson A., Gronlund A. (2017). A conceptual framework for e-learning in developing countries: A critical review of research challenges. The Electronic Journal in Developing Countries, 38(1), 1-16. https://doi.org/10.1002/j.16814835.2009.tb00271.x

Araneta, A., Carrasco, B., Rahemtulla, H., Balgos, S., \& Sy, S. (2021). Mapping digital poverty in $\mathrm{PH}$. https://business.inquirer.net/318223/mapping-digital-povertyin-ph

Arinto, P. (2016). Issues and challenges in open and distance e-learning: Perspectives from the Philippines. International Review of Research in Open and Distributed Learning, 17(2). https://doi.org/10.19173/irrodl.v17i2.1913

Asio, J. M. R., \& Bayucca, S. (2021). Spearheading education during the COVID-19 rife: Administrators' level of digital competence and schools' readiness on distance learning. Journal of Pedagogical Sociology and Psychology, 3(1), 19-26. https:// doi.org/10.33902/JPSP.2021364728

Astalin, P. (2013). Qualitative research designs: A conceptual framework. International Journal of Social Sciences \& Interdisciplinary Research, 2(1). Indianresearchjournals.com

Authority, P.S. (2020). Farmers, fisherfolks, individuals residing in rural areas and children posted the highest poverty incidences among the basic sectors in 2018. https://psa.gov.ph/poverty-press-releases/nid/162541

Authority, P. S. (2019). Proportion of poor Filipinos registered at 21.0 percent in the first semester of 2018. https://psa. gov. ph/content/proportion-poor-filipinosregistered-210-percent-first-semester-2018.

Averia, L. (2020). Security challenges in the online learning environment. https://www.manilatimes.net/2020/10/07/opinion/columnists/topanalysis/s ecurity-challenges-in-the-online-learning-environment/777325/ 
Avila, E. C., \& Genio, A. M. G. J. (2020). Motivation and learning strategies of education students in online learning during pandemic. Psychology and Education Journal, 57(9), 1608-1614. https://doi.org/10.17762/ pae.v57i9.506

Babbie, E. R., (2010). The practice of social research (12 th ed.). Belmont, CA: Wadsworth Cangage. https:/ / silo.pub/the-practice-of-social-research-12th-edition.html

Balram, A. (2020). How online learning can affect student health. https://www.jhunewsletter.com/article/2020/04/how-online-learning-canaffect-student-health

Bao, W. (2020). COVID-19 and online teaching in higher education: A case study of Peking University. Human Behavior \& Emerging Technology, 1-3. https://doi.org/10.1002/hbe2.191

Baticulon, R., Sy, J., Alberto, N. R., Baron, M. B., Mabulay, R. E., Rizada, L. G., Tiu, C. J., Clarion, C., \& Reyes, J. C. (2021). Barriers to online learning in the time of COVID-19: A national survey of medical students in the Philippines. Medical Science Educator, 31, 615-626. https:// doi.org/10.1007/s40670-021-01231-z

Bergdahl, N., Nouri, J., \& Fors, U. (2020). Disengagement, engagement and digital skills in technology- enhanced learning. Education and information technologies, 25(2), 957-983. https://doi.org/10.1007/s10639019-09998-w

Bergen, E., Zuijen, T., Bishop, D., \& Jong, P. F. (2016). Why are home literacy environment and children's reading skills associated? What parental skills reveal. Reading Research Quarterly, 52, 147-160. https:// doi.org/10.1002/rrq.160

Bonk, C., \& Zhang, K. (2006). Introducing the R2D2 model: Online learning for the diverse learners of this world. Distance Education, 27(2), 249-264. https://doi.org/10.1080/01587910600789670

Casey, J., \& Wilson, P. (2005). A practical guide to providing flexible learning in further and higher education. Glasgow: Quality Assurance Agency for Higher Education.https://www.researchgate.net/publication/228359222_A_practical_g uide_to_providing_flexible_learning_in_further_and_higher_education

Chakraborty, I., \& Maity, P. (2020). COVID-19 outbreak: Migration, effects on society, global environment and prevention. Science of the Total Environment. https:// doi.org/10.1016/j.scitotenv.2020.138882

Cheung, S. K. (2012). A study on the use of mobile devices for distance learning. Paper presented in the International Conference on Hybrid Learning, https://doi.org/10.1007/978-3-642-32018-7_9

Cheung, S. K. (2018). A study on the pattern and trend of students' typical usage of mobile devices in learning activities. Paper presented in International Conference on Technology in Education, 89-100. https://doi.org/10.1007/978-981-13-0008-0_9

Chua, E. R., Sibbaluca, B., Miranda, R., Palmario, G., Moreno, R., \& Solon, J. P. (2020). The status of the implementation of the flexible learning classroom in selected higher education institutions in Rehion IV-A amidst the COVID-19 Crisis. Journal of Critical Reviews, 12(11), 253-258. http://www.jcreview.com/fulltext/197-1590731776.pdf

Commission on Higher Education. (2020). COVID-19 updates. https://ched.gov.ph/wpcontent/uploads/CHED-COVID-19-Advisory-No.-6.pdf

Copeland, W. E., McGinnis, E., Bai, Y., Adams, Z., Nardone, H., Devadanam, V., \& Hudziak, J. J. (2021). Impact of COVID-19 pandemic on college student mental health and wellness. Journal of the American Academy of Child $\mathcal{E}$ Adolescent Psychiatry, 60(1), 134-141. https:// doi.org/10.1016/j.jaac.2020.08.466

Cueto, L. J., \& Agaton, C. B. (2021). Pandemic and typhoon: Positive impacts of a double disaster on mental health of female students in the Philippines. Behavioral Sciences, 11(5), 64. https:// doi.org/10.3390/ bs11050064 
Cull, S. (2010). The challenge of keeping our students engaged. https://serc.carleton.edu/NAGTWorkshops/online/motivation.html

Day, T., Chang, I. C. C., Chung, C. K. L., Doolittle, W. E., Housel, J., \& McDaniel, P. N. (2021). The immediate impact of COVID-19 on postsecondary teaching and learning. The Professional Geographer, 73 (1), 1-13. https://doi.org/10.1080/00330124.2020.1823864

Dhawan, S. (2020). Online learning: A panacea in the time of COVID-19 crisis. Journal of Educational Technology Systems, 5-22. https://doi.org/10.1177/0047239520934018

DICT (2017). National Broadband Plan: Building Info structures for a Digital Nation. Diliman, Quezon City. https://dict.gov.ph/wp-content/uploads/2017/09/2017.08.09National-Broadband-Plan.pdf

Doerschuk, P., Bahrim, C., Daniel, J., Kruger, J., Mann, J., \& Martin, C. (2016). Closing the gaps and filling the STEM pipe line: A multidisciplinary approach. Journal of Science Education and Technology, 25(4), 682-695. https://doi.org/10.1007/s10956-016-9622-8

Donitsa-Schmidt, S., \& Ramot, R. (2020). Opportunities and challenges: Teacher education in Israel in the Covid-19 pandemic. Journal of Education for Teaching, 46(4), 586-595. https:/ / doi.org/10.1080/02607476.2020.1799708

Dube, B. (2020). Rural online learning in the context of COVID-19 in South Africa: Evoking an inclusive education approach. Multidisciplinary Journal of Educational Research, 10(2), 135-157. https://doi.org/10.4471/remie.2020.5607

Dubey, S.,\& Piroska, B. (2019). Exploration of factors affecting learners' motivation in elearning. International Journal of Scientific Research in Computer Science, Engineering and Information Technology, 5(2), $2456 \quad-\quad 3307$. https://doi.org/10.32628/CSEIT1952307

Edge, W. D., \& Loegering, J. P. (2000). Distance education: Expanding learning opportunities. Wildlife Soc. Bull, 28, 522-533. https://experts.umn.edu/en/publications/distance-education-expandinglearning-opportunities

Esquire Philippines. (2020). So, yeah, the Philippines has expensive turtle internet. https://www.esquiremag.ph/culture/tech/philippines-internet-a0020320200820

Fawaz, M., Al Nakhal, M., \& Itani, M. (2021). COVID-19 quarantine stressors and management among Lebanese students: A qualitative study. Current Psychology, 1-8. https:/ / doi.org/10.1007/s12144-020-01307-w

Finol, M. O. (2020). Asynchronous vs. synchronous learning: A quick overview. https:/ / www.brynmawr.edu/blendedlearning/asynchronous-vs-synchronouslearning-quick-overview

Fleming, N., Ford, C., \& King, M. (2020). In rural and urban communities, kids still struggle to get online.https://www.edutopia.org/article/rural-and-urbancommunities-kids-still-cant-get-online

Franchi, T. (2020). The impact of the Covid-19 pandemic on current anatomy education and future careers: A student's perspective. Anatomical Sciences Education,13 (3), 312-315. https://doi.org/10.1002/ase.1966

Friedman, J. (2020). Tackle challenges of online classes due to COVID-19. https://www.usnews.com/education/best-colleges/articles/how-to-overcomechallenges-of-online-classes-due-to-coronavirus

Gamage, K.A., Silve, E.K.D., \& Gunawardhana, N. (2020). Online delivery and assessment during COVID-19: Safeguarding academic integrity. Education Sciences, 10(11), 301. https:// doi.org/10.1016/S1473-3099(20)30440-0 
George, R., \& Luke, R. (1995). The critical place of information literacy in the trend towards flexible delivery in higher education contexts. https://doi.org/10.1080/00048623.1996.10754977

Gilbert, B. (2015). Online learning revealing the benefits and challenges. Journal of Public Affairs Education,19 199-215. https:/ / fisherpub.sjfc.edu/cgi/viewcontent.cgi?article=1304\&context=educatio n_ETD_masters

Gillett-Swan, J. (2017). The challenges of online learning: supporting and engaging the isolated learner. Journal of Learning Design, 10(1), https://doi.org/ 10.5204/jld.v9i3.293

Gonzalez, T., De La Rubia, M. A., Hincz, K. P., Comas-Lopez, M., Subirats, L., Fort, S., \& Sacha, G. M. (2020). Influence of COVID-19 confinement on students' performance in higher education. PLoS One, 15 (10), e0239490. https://doi.org/10.35542/osf.io/9zuac

Gooding, Y. (2001). The relationship between parental educational level and academic success of college freshmen. Retrospective Theses and Dissertations. 429. https://doi.org/10.31274/rtd-180813-12012

Haleem, A., Javaid, M., \& Vaishya, R., \& Deshmukh, S. G. (2020). Areas of academic research with the impact of COVID-19. The American Journal of Emergency Medicine, 1524-1526. https://doi.org/10.1016/j.ajem.2020.04.022

Hampton, K. N., Fernandez, L., Robertson, C. T., \& Bauer, J. M. (2020). Broadband and Student Performance Gaps. https:/ / doi.org/10.25335/BZGY-3V91

Hossain, Y., (2020). Conducting online classes in rural areas is a big challenge because of the digital divide. A perspective from a school in Haryana, India. https://edufinance.org/latest/blog/2020/conducting-online-classes-in-ruralareas-is-a-big-challenge-because-of-the-digital-divide-a-perspective-from-aschool-in-haryana-india

Huang, Q. (2019). Comparing teacher's roles of F2F learning and online learning in a blended English course. Computer Assisted Language Learning, 32(3), 190-209. https:// doi.org/10.1080/09588221.2018.1540434

Idris, M., Hussain, S., \& Ahmad, N. (2020). Relationship between Parents' Education and their children's Academic Achievement. https://doi.org/10.46662/jass-vol7iss2-2020(82-92)

Islam, N., Beer, M., \& Slack. F. (2015). E-Learning challenges faced by academics in higher education: A literature review. Journal of Education and Training Studies, 3(5), https:// doi.org/10.11114/jets.v3i5.947

Joan, R. (2013). Flexible learning as new learning design in classroom process to promote quality education. I-Managers on Journal on School Education Technology, 9(1), https://files.eric.ed.gov/fulltext/EJ1098325.pdf

Joaquin, J., Biana, H., \& Dacela M.A. (2020). Education leadership and the Covid-19 crisis. Frontiers in Education, 5. https://doi.org/10.3389/feduc.2020.576371

Kapasia, N., Paul, P., Roy, A., Saha, J., Zaveri, A., Mallick, R., \& Chouhan, P. (2020). Impact of lockdown on learning status of undergraduate and postgraduate students during COVID-19 pandemic in West Bengal. India. Children and Youth Services Review, 116. https://doi.org/10.1016/j.childyouth.2020.105194

Khalil, R., Mansour, A. E., Fadda, W. A., Almisnid, K., Aldamegh, M., Al-Nafeesah, A., \& Al-Wutayd, O. (2020). The sudden transition to synchronized online learning during the COVID-19 pandemic in Saudi Arabia: A qualitative study exploring medical students' perspectives. BMC Medical Education, 20(1), 1-10. https:// doi.org/10.1186/s12909-020-02208-z 
Khan, R. M. A., Iqbal, N., \& Tasneem, S. (2015). The Influence of Parents Educational Level on Secondary School Students Academic Achievements in District Rajanpur. Journal of Education and Practice, 6(16), 76-79. https://eric.ed.gov/?id=EJ1079955

Larreamendy-Joerns, J., \& Leinhardt, G. (2006). Going the distance with online education. Review of Educational Research, 76(4), 567-605. https://doi.org/10.3102/00346543076004567

Lepp, A., (2019). Off task during online learning: Kent state study finds student multitasking increases in online courses compared to face-to-face courses. https://www.kent.edu/kent/news/kent-state-study-finds-studentmultitasking-increases-online-courses

Li, Z., \& Qiu, Z. (2011). How does family background affect children's educational achievement?. The Journal of Chinese Sociology, 5(13), https://doi.org/10.1186/s40711-018-0083-8.

Lin, T., \& Lv, H. (2017). The effects of family income on children's education: An empirical analysis of CHNS data. Paper presented in the International Conference on Information Technology and Career Education Asian Academic Press. http://rmhe.oss-cnhangzhou.aliyuncs.com/2017_vol.4/icitce2017_02002.pdf

Lincoln Y., Guba E., \& Pilotta J. (1985). Naturalistic inquiry. International Journal of Intercultural Relations, 9(4), 438 - 439. https://doi.org/10.1016/01471767(85)90062-8

Llego, M.A. (2020). DepEd learning delivery modalities for school year 2020-2021. https://www.teacherph.com/deped-learning-delivery-modalities/

$\mathrm{Lv}, \mathrm{H}$. (2017). The effects of family income on children's education: An empirical analysis of CHNS data. https://doi.org/10.24104/rmhe/2017.04.02002

Macintyre, R. \& Macdonald, J. (2011). Remote from what? Perspective of distance learning students in remote rural areas of Scotland. International review of Research in Open and Distance Learning, 12(4). https:/ / files.eric.ed.gov/fulltext/EJ927007.pdf

Marasigan, L. (2020). ITU flags connectivity gaps, Internet access in Philippines, other nations. https://businessmirror.com.ph/2020/12/01/itu-flags-connectivity-gapsinternet-access-in-philippines-other-nations/

Markova, T., Glazkova, I., \& Zaborova, E. (2017). Quality issues of online distance learning. file:///C:/Users/Personal/Desktop/online\%20distance\%20learning/S1877042 817300435.html

Means, B., Toyama, Y., Murphy, R., Bakia, M., \& Jones, K. (2010). Evaluation of evidencebased practices in online learning: Meta-analysis and review of online learning studies. https://www2.ed.gov/rschstat/eval/tech/evidence-basedpractices/finalreport.pdf

Morgan, P. L., Farkas, G., Hillemeier, M. M., \& Maczuga, S. (2009). Risk factors for learning-related behavior problems at 24 months of age: Population-based estimates. Journal of Abnormal Child Psychology, 37, 401-413. https://doi.org/10.1007/s10802-008-9279-8

Muijs, D. (2010). Doing quantitative research in education with SPSS (2nd ed.). London: SAGE Publications. https://eprints.soton.ac.uk/165853/

Muller, C., Stahl, M., Alder, M., \& Muller, M. (2018). Learning effectiveness and students' perceptions in a flexible learning course. European Journal of Open, Distance and E-Learning, 21(2), 44-52. https://doi.org/10.2478/eurodl-2018-0006

Naidu, S., Chand, A., Pandaram, A., \& Chand, A. (2017). Fostering teaching excellence through first year distance and flexible learning education: A study of 12 pacific 
island countries. International Journal of Instructional Technology and Distance Learning,14 (5), 59-71. http://repository.usp.ac.fj/id/eprint/9957

National ICT Household Survey. (2019). https://dict.gov.ph/ictstatistics/wpcontent/uploads/2020/07/NICTHS-Executive-Summary_Updated_July-17.pdf

National Statistics Office. (2010). Family income and expenditure survey. https://psa.gov.ph/income-expenditure/fies

National Telecommunications Commission (2015). Rules on the measurement of fixed broadband/ internet access service. https://ncr.ntc.gov.ph/wpcontent/uploads/2019/Memorandum_Circulars/2015/MC-07-08-2015.pdf

NCERT (2020). Over $27 \%$ students have no access to gadgets for online classes. http://www.coastaldigest.com/india-top-story/over-27-students-have-noaccess-gadgets- online-classes-ncert.

Nouri, J. (2019). Students multimodal literacy and design of learning during self-studies in higher education. Technology, Knowledge and Learning, 24(4), 683-698. https:// doi.org/10.1007/s10758-018-9360-5

Okafor, I., Owede, V., Uyanne, E., \& Chibundum, C. (2018). Parents' educational background and academic performance of senior secondary students in civic education in Ilorin metropolis. African Journal of Interdisciplinary Studies, 11 (2), 99-107. https://docplayer.net/169243813- Parents-educational-

background-and-academic-performance-of-senior-secondary-students-in-civiceducation-in-ilorinmetropolis.html

Omotayo, F., \& Haliru, A. R. (2020). Perception of task-technology fit of digital library among undergraduates in selected universities in Nigeria. The Journal of $\begin{array}{lll}\text { Academic Librarianship, } & 102097 .\end{array}$ https://doi.org/10.1016/j.acalib.2019.102097

Oztok, M., Zingaro, D., Brett, C., \& Hewitt, J. (2013). Exploring asynchronous and synchronous tool use in online courses. Computer Education, 60, 87-94. https://doi.org/10.1016/j.compedu.2012.08.007

Pappas, C. (2015). Synchronous learning advantages and disadvantages in corporate training. https://elearningindustry.com/synchronous-learning-advantages-anddisadvantages-in-corporate-training

Perez, A. (2021). Groups say students losing interest in studies amid distance learning. https://news.abs-cbn.com/news/04/05/21/groups-say-students-losinginterest-in-studies-amid-distance-learning

Pham, T., \& Nguyen, H. (2020). COVID-19: Challenges and opportunities for Vietnamese higher education. Higher Education in Southeast Asia and beyond, 8, 22-24. https:/ / headfoundation.org/2020/06/09/covid-19-challenges-andopportunities-for-vietnamese-higher-education/

Philippine Statistics Authority. (2020). Farmers, Fisherfolks, Individuals Residing in Rural Areas and Children Posted the Highest Poverty Incidences Among the Basic Sectors in 2018. https:/ / psa.gov.ph/ poverty-press-releases

Philippine Statistical Authority. (2019). National ICT Household Survey. https:/ / dict.gov.ph/ictstatistics/2019-national-ict-household-survey-results/

Polkinghorne D, E. (1995). Narrative configuration in qualitative analysis. International Journal of Qualitative Studies in Education, 8(1), 5-23. https://doi.org/10.1080/0951839950080103

Reyes-Chua, E., Sibbaluca, B. G., Miranda, R. D., Palmario, G. B., Moreno, R. P., \& Solon, J. P. T. (2020). The status of the implementation of the e-learning classroom in selected higher education institutions in region IV-A amidst the COVID-19 crisis. Journal of Critical Reviews, 7(11), 253-258. DOI: http://dx.doi.org/10.31838/jcr.07.11.41 
Rotas, E. E., \& Cahapay, M. B. (2020). Difficulties in remote learning: Voices of Philippine university students in the wake of COVID-19 crisis. Asian Journal of Distance Education, 15(2), 147-158. https://doi.org/10.5281/zenodo.4299835

Richards, L. (2006). Qualitative research design. SAGE Publication. https://www.sagepub.com/sites/default/files/upmbinaries/13172_Chapter4.pdf

Rost, M. (2019). A dive into the challenges of online distance learning. Pearson. https://www.english.com/blog/a-dive-into-the-challenges-of-online-distancelearning/

Saifi, S., \& Mehmood, T. (2011). Effects of socio-economic status on students' achievement. International Journal of Social Sciences and Education, 1(2), 119-128. https:/ / doi.org/10.13140/RG.2.2.19730.71369

Salac, R. A., \& Kim, Y. (2016). A study on the internet connectivity in the Philippines. Asia Pacific Journal of Business Review, 1(1), 67-88. https://scholar.google.com/scholar?hl=en\&as_sdt=0\%2C5\&q=A+Study+on+Th e+Internet+Connectivity+in+The+Philippines\&btnG=

Salanga, M. G. C., \& Bernardo, A. B. (2016). Filipino students' reasons for not being motivated in school: Insights into their implicit beliefs about motivation and learning. In R.king \& A.Bernardo (Eds.), The psychology of Asian learners. Springer, Singapore. https://doi.org/10.1007/978-981-287-576-1_6

Salman, J., (2020). Hundreds of thousands of students still can't access online learning. https://hechingerreport.org/hundreds-of-thousands-ofstudents-still-cantaccess-online-learning/

Schwanz, K., Palm, L., Hill-Chapman, C., \& Broughton, S. (2014). College Students' Perceptions of Relations with Parents and Academic Performance. American Educational Research Journal 2(1), 3 - 17. https://doi.org/10.12691/education-2-13

SEAMEO Congress. (2021). Transforming Southeast Asian Education, Science and Culture in the Digital Age. https:/ / congress2021.seameo.org/images/Download/Concept\%20Note/SEAM EO\%20Congresss\%20ConceptNote_(25Mar2021).pdf

Senthil, V. (2018). Does the more internet usage provide good academic grades?.

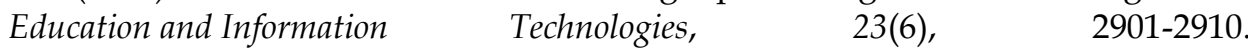
https:/ / doi.org/10.1007/s10639-018-9749-8

Shore, J. (2020). Problems in online class. https:/ / file:/ / C:/Users/julie/Desktop/research\%20example.pdfeducation.se attlepi.com/problems-online-classes-1132.html

Shurville,S., O'Grady,T., \& Mayall,P. (2008). Educational and institutional flexibility of Australian educational software. Campus-Wide Information Systems, Emerald $\begin{array}{llllll}\text { Group Publishing } & \text { Limited, } & 25 & \text { (2), } & 74 & \text { - }\end{array}$ https:// doi.org/10.1108/10650740810866576

Simbulan, N. (2020). COVID-19 and its impact on higher education in the Philippines. Higher Education in Southeast Asia and beyond, 8, 15-18. https://headfoundation.org/wp-content/uploads/2020/11/HESB-8 COVID19_2020.pdf

Simonson, M. \& Berg Gary, A. (2016). Distance learning. https://www.britannica.com/topic/distance-learning

Singh, V., \& Thurman, A. (2019). How many ways can we define online learning? A systematic literature review of definitions of online learning (1988-2018). American Journal of Distance Education, 33(4), 289-306. https://doi.org/10.1080/08923647.2019.1663082 
Sintema, E. J. (2020). Effect of COVID-19 on the performance of grade 12 students: Implications for STEM education. Eurasia Journal of Mathematics, Science and Technology Education, 16(7). https:// doi.org/10.29333/ejmste/7893

Sun, J. C., \& Rueda, R. (2012). Situational interest, computer self-efficacy and selfregulation: Their impact on student engagement in distance education. British Journal of Educational Technology, 43(2), 191-204. https://doi.org/10.1111/j.14678535.2010.01157.x

Suryaman, M., Cahyono, Y., Muliansyah, D., Bustani, O., Suryani, P., Fahlevi, M., \& Munthe, A. P. (2020). COVID-19 pandemic and home online learning system: Does it affect the quality of pharmacy school learning?. Systematic Reviews in Pharmacy, 11, 524-530. https://search.bvsalud.org/global-literature-on-novelcoronavirus-2019-ncov/resource/en/covidwho-846299

The Irish Times. (2020). Poor wifi, home distractions: Students on the reality of online classes. https://www.irishtimes.com/news/education/poor-wifi-home-distractionsstudents-on-the-reality-of-online-classes- 1.4233158

The Manila Times. (2021). 39\% of Filipino families with distance learners have 'strong' internet connection - SWS. https://www.manilatimes.net/2021/03/06/news/39of-filipino-families-with-distance-learners-have-strong-internet-connectionsws $/ 847921$

Tientcheu, V. T. L. (2021). Challenges of online classes due to COVID-19. https://www.researchgate.net/publication/350089987_Challenges_of_Online_ Classes_due_to_COVID-19

Toquero, C. M. (2020). Challenges and opportunities for higher education amid the COVID-19 pandemic: The Philippine context. Pedagogical Research, 5(4), em0063. https://doi.org/10.29333/pr/7947

Tuckman, B. (2007). The effect of motivational scaffolding on procrastinators' distance learning outcomes. Computers \& Education, 49 (2), 414-422. https://doi.org/10.1016/j.compedu.2005.10.002

Tuner, S. (2020). Many students lack motivation for online learning. https://granitebaytoday.org/distance-learning-presents-challenges-to-studenteducation/

UNESCO. (2020). Global monitoring of school closures caused by COVID-19. https://en.unesco.org/covid19/educationresponse

University of Perpetual Help [UPH]. (2020). The Benefits of flexible learning. https:// perpetualdalta.edu.ph/2020/10/02/the-benefits-of-flexible-learning/

Usher, M., \& Barak, M. (2020). Team diversity as a predictor of innovation in team projects of face-to face and online learners. Computers \& Education, 144. https://doi.org/10.1016/j.compedu.2019.103702

Van Doorn, J. R., \& Van Doorn, J. D. (2004). The quest for knowledge transfer efficacy: Blended teaching, online and in-class, with consideration of learning typologies for non-traditional and traditional students. Frontiers in Psychology, 5(324). https://doi.org/10.3389/fpsyg.2014.00324

Villarin, J. R. T. (2020). Enhanced community quarantine. http://www.ateneo.edu/enhanced-community-quarantine

Wanner, T., \& Palmer, E. (2015). Personalising learning: Exploring student and teacher perceptions about flexible learning and assessment in a flipped university

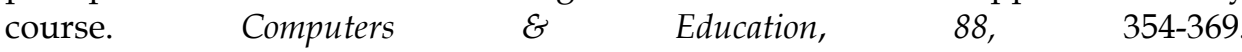
https:// doi.org/10.1016/j.compedu.2015.07.008

Welser, H.T., Khan, M.L., \& Dickard, M. (2019). Digital remediation: Social support and online learning communities can help offset rural digital inequality. Information, 
$\begin{array}{llll}\text { Communication } \quad \text { and } & \text { Society, } & \text { 717-723. }\end{array}$ https://doi.org/10.1080/1369118X.2019.1566485

Wickramanayake, L., \& Muhammad Jika, S. (2018). Social media use by undergraduate students of education in Nigeria: A survey. The Electronic Library, 36(1), 21-37. https:/ / doi.org/ /10.1108/EL-02-2017-0023

World Bank. (2020). Monitoring global poverty. https://doi.org/10.1596/978-1-4648-16024_ch1

World Bank. (2020). Remote learning and COVID-19. The use of educational technologies at scale across an education system as a result of massive school closings in response to the COVID-19 pandemic to enable distance education and online learning.http://documents.worldbank.org/curated/en/266811584657843186/pd f/Rapid-Response-Briefing-Note-Remote-Learning-and-COVID-19Outbreak.pdf

Yan Z. (2020). Unprecedented pandemic, unprecedented shift, and unprecedented opportunity. Human Behavior \& Emerging Technologies, 1-3. https://doi.org/10.1002/hbe2.192 